\title{
Preparation and Catalytic Study on a Novel Amino-functionalized Silica-coated Cobalt Oxide Nanocomposite for the Synthesis of Some Indazoles
}

\author{
Mohammad Ali Ghasemzadeh,*,1 Bahar Molaei, ${ }^{2}$ \\ Mohammad Hossein Abdollahi-Basir ${ }^{1}$ and Farzad Zamani ${ }^{3}$ \\ ${ }^{1}$ Department of Chemistry, Qom Branch, Islamic Azad University, Qom, I. R. Iran \\ ${ }^{2}$ Young Researchers and Elite Club, Shahr-e-Qods Branch, Islamic Azad University, Tehran, Iran \\ ${ }^{3}$ School of Chemistry, University of Wollongong, New South Wales, 2522, Australia \\ *Corresponding author: E-mail: Ghasemzadeh@qom-iau.ac.ir
}

Received: 18-08-2016

\begin{abstract}
In this research an efficient synthesis of a novel nanocomposite including $\mathrm{SiO}_{2} @$ (3-aminopropyl)triethoxysilane-coated cobalt oxide $\left(\mathrm{Co}_{3} \mathrm{O}_{4}\right)$ nanocomposite has been reported by three step method. The structure and magnetic characterization of $\mathrm{Co}_{3} \mathrm{O}_{4} @ \mathrm{SiO}_{2} @ \mathrm{NH}_{2}$ have been done by using various spectroscopic analyses which include FT-IR, X-ray powder diffraction, scanning electron microscopy, transmission electron microscopy, energy dispersive X-ray spectroscopy and vibrating sample magnetometry. Amino-functionalized $\mathrm{SiO}_{2}$ coated $\mathrm{Co}_{3} \mathrm{O}_{4}$ nanocomposite exhibited superparamagnetic behavior and strong magnetization at room temperature. The average crystallite sizes of the $\mathrm{Co}_{3} \mathrm{O}_{4}$ are $23.7 \mathrm{~nm}$. The obtained magnetic nanocomposite showed excellent catalytic activity as a new heterogeneous magnetic catalyst for the synthesis of some indazole derivatives under mild reaction conditions along with high level of reusability.
\end{abstract}

Keywords: $\mathrm{Co}_{3} \mathrm{O}_{4} @ \mathrm{SiO}_{2} @ \mathrm{NH}_{2}$, heterogeneous catalyst, spectroscopic analysis, indazole derivatives, nanocomposite

\section{Introduction}

Over the last decade, organic-inorganic magnetic nanocomposites have become interesting as magnetic catalysts in both academic and industrial fields. ${ }^{1-3}$ The spinel cobalt oxide $\mathrm{Co}_{3} \mathrm{O}_{4}$ is a magnetic semiconductor and widely used catalyst for a variety of reactions. ${ }^{4-5}$ The use of this magnetic nanoparticle catalyst can address the isolation and recycling problem encountered in many heterogeneous and homogenous catalytic reactions. Most importantly, the magnetic-supported catalysts show not only high catalytic activity but also high degree of chemical stability. The $\mathrm{Co}_{3} \mathrm{O}_{4}$ surface has a strong affinity for silica, and the cobalt-oxide NPs were easily coated with silica via the sol-gel process. ${ }^{6}$ It has been exhibited that the formation of silica coating on the surface of $\mathrm{Co}_{3} \mathrm{O}_{4}$ NPs can hinder their aggregation and keep their chemical stability. ${ }^{7} \mathrm{In}$ addition, the silanol $(\mathrm{Si}-\mathrm{OH})$ groups, which have often located in the terminal of silica coating surface, $\mathrm{SiO}_{2}$ is stab- le under acidic conditions and inert to redox reactions, as compared with the organic coating materials, and hence functions like an ideal shell composite to protect the inner $\mathrm{Co}_{3} \mathrm{O}_{4}$ partciles. Silica-coated $\mathrm{Co}_{3} \mathrm{O}_{4}$ nanocomposite, i.e., $\mathrm{Co}_{3} \mathrm{O}_{4} @ \mathrm{SiO}_{2}$, has recently been investigated for potential biomedical applications. ${ }^{8-10}$ Additionally, the $\mathrm{SiO}_{2}$ coating shell has an abundance of surface hydroxyl groups which can be easily coupled with organosilanes by formation of $\mathrm{Si}-\mathrm{O}-\mathrm{Si}$ covalent bonds. The importance of this field is highlighted by the use of bio molecules which control the self-assembly of nanodevices. ${ }^{11-13}$ This led to the idea of preparing an active catalyst, $\mathrm{Co}_{3} \mathrm{O}_{4} @ \mathrm{SiO}_{2} @ \mathrm{NH}_{2}$, through morphology-controlled synthesis which ensure that faces which are active specifically are exposed predominantly at the surface. As well as, to the best of our knowledge, no attempt has been made to synthesis of $\mathrm{Co}_{3} \mathrm{O}_{4} @ \mathrm{SiO}_{2} @ \mathrm{NH}_{2}$ nanostructures. In this study, a novel $\mathrm{Co}_{3} \mathrm{O}_{4}$ magnetic nanocomposite was developed by grafting amino groups covalently onto the surfaces of $\mathrm{Co}_{3} \mathrm{O}_{4} @ \mathrm{SiO}_{2}$ nanocomposite. 
The resulted nanocomposite was characterized by Fourier transform infrared (FTIR), transmission electron microscopy (TEM), X-ray powder diffraction (XRD), scanning electron microscopy (SEM) and vibrating sample magnetometer (VSM). This study on the synthesis of $\mathrm{Co}_{3} \mathrm{O}_{4} @ \mathrm{Si}$ $\mathrm{O}_{2} @ \mathrm{NH}_{2}$ nanocomposite may open up new routes in the research for highly active catalysts.

In continuing our efforts towards the development of efficient and environmentally benign heterogeneous catalysts, ${ }^{14-18}$ herein, $\mathrm{Co}_{3} \mathrm{O}_{4} @ \mathrm{SiO}_{2} @ \mathrm{NH}_{2}$ nanocomposite was prepared as a highly efficient magnetic catalyst by a simple method. The main goal of this catalytic synthesis was to introduce a novel and effective magnetic nanocomposite to expand the use of these types of composites for organic reactions. In order to investigate the catalytic activity of this magnetic catalyst, synthesis of some indazole derivatives have been done via two-component reactions.

\section{Experimental}

\section{1. Chemicals and Apparatus}

Chemicals were purchased from the Sigma-Aldrich and Merck in high purity. All of the materials were of commercial reagent grade and have been used without further purification. The $\alpha, \alpha$-bis (substituted-arylidene) cycloalkanones were synthesized via aldol condensation as described previously. ${ }^{19,20}$ All melting points are uncorrected and were determined in capillary tube on Boetius melting point microscope. The ultrasonic irradiation was used in reactions by a multi-wave ultrasonic generator (Sonicator 3200; Bandelin, MS 73, Germany), equipped with a converter/transducer and titanium oscillator (horn), $12.5 \mathrm{~mm}$ in diameter, operating at $20 \mathrm{kHz}$ with a maximum power output of 200 W. The ultrasonic generator automatically adjusted the power level. ${ }^{1} \mathrm{H}$ NMR and ${ }^{13} \mathrm{C}$ NMR spectra were obtained on Bruker $400 \mathrm{MHz}$ spectrometer with $\mathrm{CDCl}_{3}$ as solvent using TMS as an internal standard. FT-IR spectrum was recorded on Magna-IR, spectrometer 550. The elemental analyses $(\mathrm{C}, \mathrm{H}, \mathrm{N})$ were obtained from a Carlo ERBA Model EA 1108 analyzer. Powder X-ray diffraction (XRD) was carried out on a Philips diffractometer of X'pert Company with mono chromatized $\mathrm{Cu} K \alpha$ radiation $(\lambda=1.5406 \AA$ ). Microscopic morphology of products was visualized by SEM (LEO 1455VP). The mass spectra were recorded on a Joel D-30 instrument at an ionization potential of $70 \mathrm{eV}$. Transmission electron microscopy (TEM) was performed with a Jeol JEM-2100UHR, operated at $200 \mathrm{kV}$. Magnetic properties were obtained on a BHV-55 vibrating sample magnetometer (VSM) made by MDK-I.R.Iran. The compositional analysis was done by energy dispersive analysis of X-ray (EDX, Kevex, Delta Class I).

\section{2. Preparation of $\mathrm{Co}_{3} \mathrm{O}_{4}$ Nanoparticles}

$\mathrm{Co}_{3} \mathrm{O}_{4} \mathrm{MNPs}$ were prepared according to previously reported procedure by Vela et. al with some modifications. ${ }^{21}$ Firstly, cobalt nitrate hexahydrate $(8.60 \mathrm{~g})$ was dissolved in $100 \mathrm{ml}$ of ethanol and the resulting mixture was stirred vigorously. Then, the mixture was heated up to $50{ }^{\circ} \mathrm{C}$ and kept for $30 \mathrm{~min}$. Finally oxalic acid $(2.14 \mathrm{~g})$ was added quickly to the solution and the reaction mixture was stirred for $2 \mathrm{~h}$ at $50{ }^{\circ} \mathrm{C}$. The formed precipitate which includes cobalt (II) oxalate was collected by centrifuges and then the prepared cobalt (II) oxalate powder was calcined at $400{ }^{\circ} \mathrm{C}$ for $2 \mathrm{~h}$ to produce $\mathrm{Co}_{3} \mathrm{O}_{4}$ nanoparticles.

\section{3. Preparation of $\mathrm{Co}_{3} \mathrm{O}_{4} @ \mathrm{SiO}_{2}$ Nanoparticles}

$\mathrm{Co}_{3} \mathrm{O}_{4} @ \mathrm{SiO}_{2}$ MNPs were prepared according to the slightly modified previously reported method by Vela et. al. ${ }^{21}$ Briefly, CTAB (2.2 g) was added to a solution of $0.5 \mathrm{~g}$ of $\mathrm{Co}_{3} \mathrm{O}_{4}$ nanoparticles in $\mathrm{EtOH}(350 \mathrm{~mL})$, and then concentrated ammonia aqueous solution $(40 \mathrm{~mL}, 28 \mathrm{wt} \%)$ was added dropwise to the reaction mixture under sonication. After the treatment for $20 \mathrm{~min}$ which followed by the addition of tetraethylorthosilicate (TEOS) $(0.4 \mathrm{~mL}$ in 10 $\mathrm{mL}$ of $\mathrm{EtOH}$ ) to the mixture under ultrasound irradiation, then solution was stirred for $20 \mathrm{~h}$ at room temperature. $\mathrm{Co}_{3} \mathrm{O}_{4}$ nanoparticles coated with porous $\mathrm{SiO}_{2}$ shell were collected by centrifugation and washed three times with deionised water and then were calcined at $600{ }^{\circ} \mathrm{C}$ for $6 \mathrm{~h}$.

\section{4. Preparation of $\mathrm{Co}_{3} \mathrm{O}_{4} @ \mathrm{SiO}_{4} @ \mathrm{NH}_{2}$ Nanocomposite}

$\mathrm{Co}_{3} \mathrm{O}_{4} @ \mathrm{SiO}_{2}$ nanoparticles $(0.5 \mathrm{~g})$ were added to the three-necked flask and ultrasonically dispersed for 15 min in dry toluene $(25 \mathrm{~mL})$. Afterwards, 1 mililiter (4.27 mmol) of 3-aminopropyltriethoxysilane (APTES) was added into the flask, and the reaction mixture was refluxed at $110^{\circ} \mathrm{C}$ with continuous stirring for $10 \mathrm{~h}$ under nitrogen atmosphere. After completion of the reaction, the resulting amine-functionalized $\mathrm{Co}_{3} \mathrm{O}_{4} @ \mathrm{SiO}_{2}$ was gathered by centrifugation and washedwith water and ethanol for several times. Finally, it was dried at $50{ }^{\circ} \mathrm{C}$ under vacuum conditions for $10 \mathrm{~h}$ (Scheme1).

Nitrogen content of the amine-grafted sample was estimated by back titration using $\mathrm{NaOH}(0.1 \mathrm{~mol} / \mathrm{L}){ }^{22-24}$ First, the known amount of the catalyst was stirred in $\mathrm{HCl}$ $(0.5 \mathrm{~mol} / \mathrm{L})$ for $30 \mathrm{~min}$. Then, the mixture was filtrated and titrated with $\mathrm{NaOH}(0.1 \mathrm{~mol} / \mathrm{L})$. Nitrogen content of the catalyst was $5.86 \mathrm{mmol} / \mathrm{g}$ using $8.54 \mathrm{mmol} / \mathrm{g}$ trimethoxysilylpropylamine.

\section{5.General Procedure for Synthesis of Some Indazole Derivatives}

In a typical procedure, a mixture of $\alpha, \alpha$-bis (substituted-arylidene) cycloalkanone (1 $\mathrm{mmol})$, phenyl hydra- 

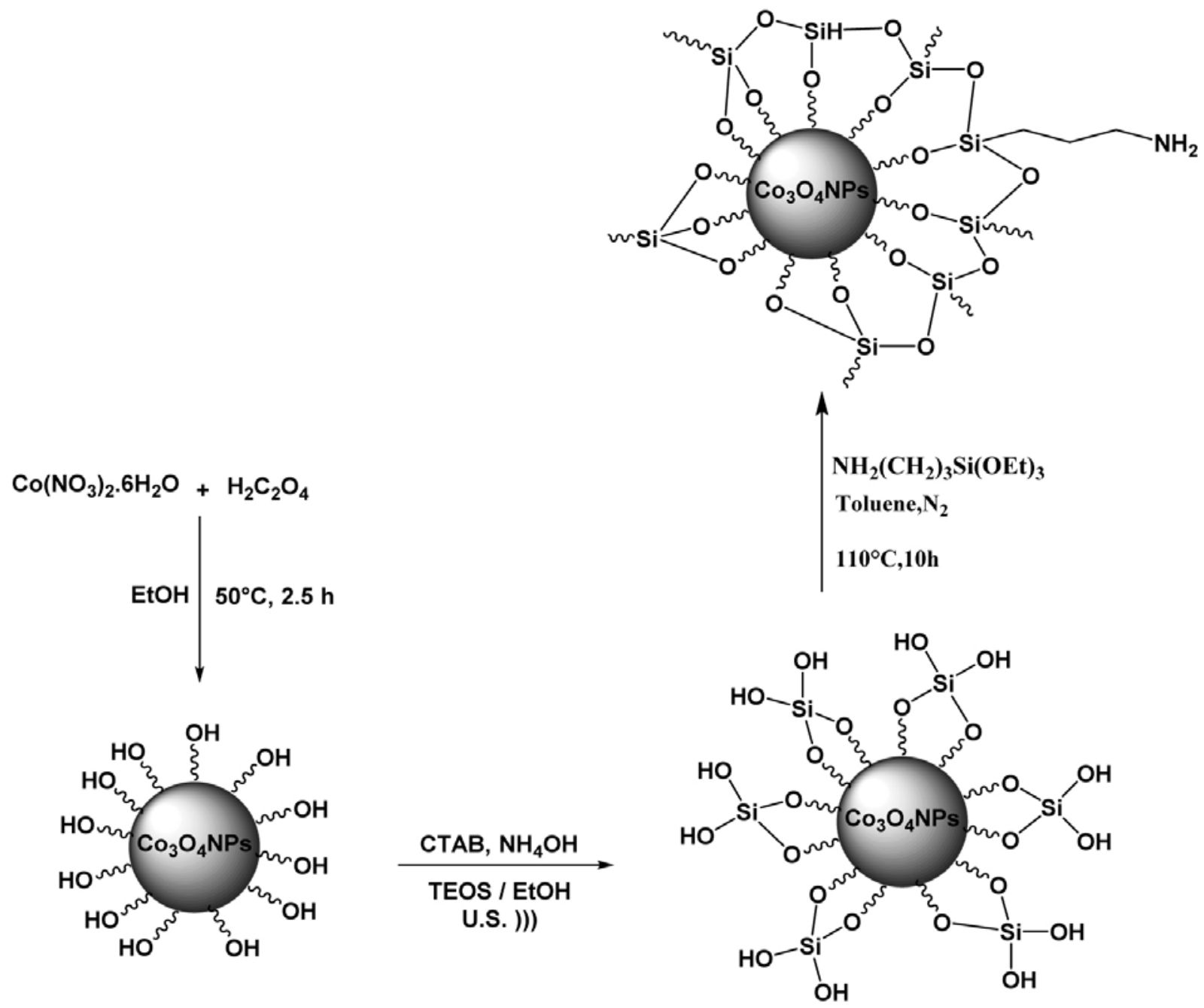

Scheme 1. Preparation steps for fabricating $\mathrm{Co}_{3} \mathrm{O}_{4} @ \mathrm{SiO}_{2} @ \mathrm{NH}_{2}$ nanocomposite

zine $(2 \mathrm{mmol})$, and $\mathrm{Co}_{3} \mathrm{O}_{4} @ \mathrm{SiO}_{2} @ \mathrm{NH}_{2}(0.003 \mathrm{~g})$ were placed in a round-bottom flask. The suspension was stirred under solvent-free conditions at $80^{\circ} \mathrm{C}$. Completion of the reaction was monitored by Thin Layer Chromatography (TLC). After termination of the reaction, the catalyst was separated from the solid crude product by using an external magnet. The precipitated solid was then collected and recrystallized from ethanol to afford the pure product.

The products were identified with ${ }^{1} \mathrm{HNMR},{ }^{13} \mathrm{CNMR}$ and FT-IR spectroscopic techniques.

\section{Results and Discussion}

\section{1. Catalyst Characterization}

The synthesis strategy of $\mathrm{Co}_{3} \mathrm{O}_{4} / \mathrm{SiO}_{2} / \mathrm{NH}_{2}$ MNPs involves three steps. Figure 1 shows the XRD patterns of prepared $\mathrm{Co}_{3} \mathrm{O}_{4}, \mathrm{Co}_{3} \mathrm{O}_{4} @ \mathrm{SiO}_{2}$ and $\mathrm{Co}_{3} \mathrm{O}_{4} @ \mathrm{SiO}_{2} @ \mathrm{NH}_{2}$. All the XRD patterns show raising background which is attributed to $\mathrm{X}$-ray fluorescence since $\mathrm{Cu}-\mathrm{K}_{\alpha}$ has been used as the X-ray source during the measurements. ${ }^{25}$

The reflections of XRD pattern of $\mathrm{Co}_{3} \mathrm{O}_{4}$ in Fig. 1a confirm the synthesis of cubic normal spinel $\mathrm{Co}_{3} \mathrm{O}_{4}$ (JCPDS file no. 42-1467). Fig. $1 \mathrm{~b}$ shows the $\mathrm{SiO}_{2}$ coating of $\mathrm{Co}_{3} \mathrm{O}_{4}$ by the presence of the new broad peak at 2è approximately $22-25^{\circ}$. As shown in Figure 1 , the characteristic peaks of $\mathrm{Co}_{3} \mathrm{O}_{4}$ are also observed for $\mathrm{Co}_{3} \mathrm{O}_{4} @ \mathrm{SiO}_{2}$ and $\mathrm{Co}_{3} \mathrm{O}_{4} @ \mathrm{SiO}_{2} @ \mathrm{NH}_{2}$, which represent the stability of the crystalline phase of $\mathrm{Co}_{3} \mathrm{O}_{4}$ nanoparticles during silica coating and surface amino-functionalization. Although these characteristic diffraction peaks are weakened in $\mathrm{Co}_{3} \mathrm{O}_{4} @ \mathrm{SiO}_{2}$ and $\mathrm{Co}_{3} \mathrm{O}_{4} @ \mathrm{SiO}_{2} @ \mathrm{NH}_{2}$, because of the silica coating and surface amino-functionalization. The average crystallite sizes of the $\mathrm{Co}_{3} \mathrm{O}_{4}$ in Figure $1(\mathrm{a}, \mathrm{b}$ and c) which have been estimated by using the Scherrer equation were $23.5,24.2$ and $26.0 \mathrm{~nm}$ respectively.

Further information about the chemical structure of $\mathrm{Co}_{3} \mathrm{O}_{4}, \mathrm{Co}_{3} \mathrm{O}_{4} @ \mathrm{SiO}_{2}$ and $\mathrm{Co}_{3} \mathrm{O}_{4} @ \mathrm{SiO}_{2} @ \mathrm{NH}_{2}$ nanocomposites have been obtained from FT-IR spectroscopy 


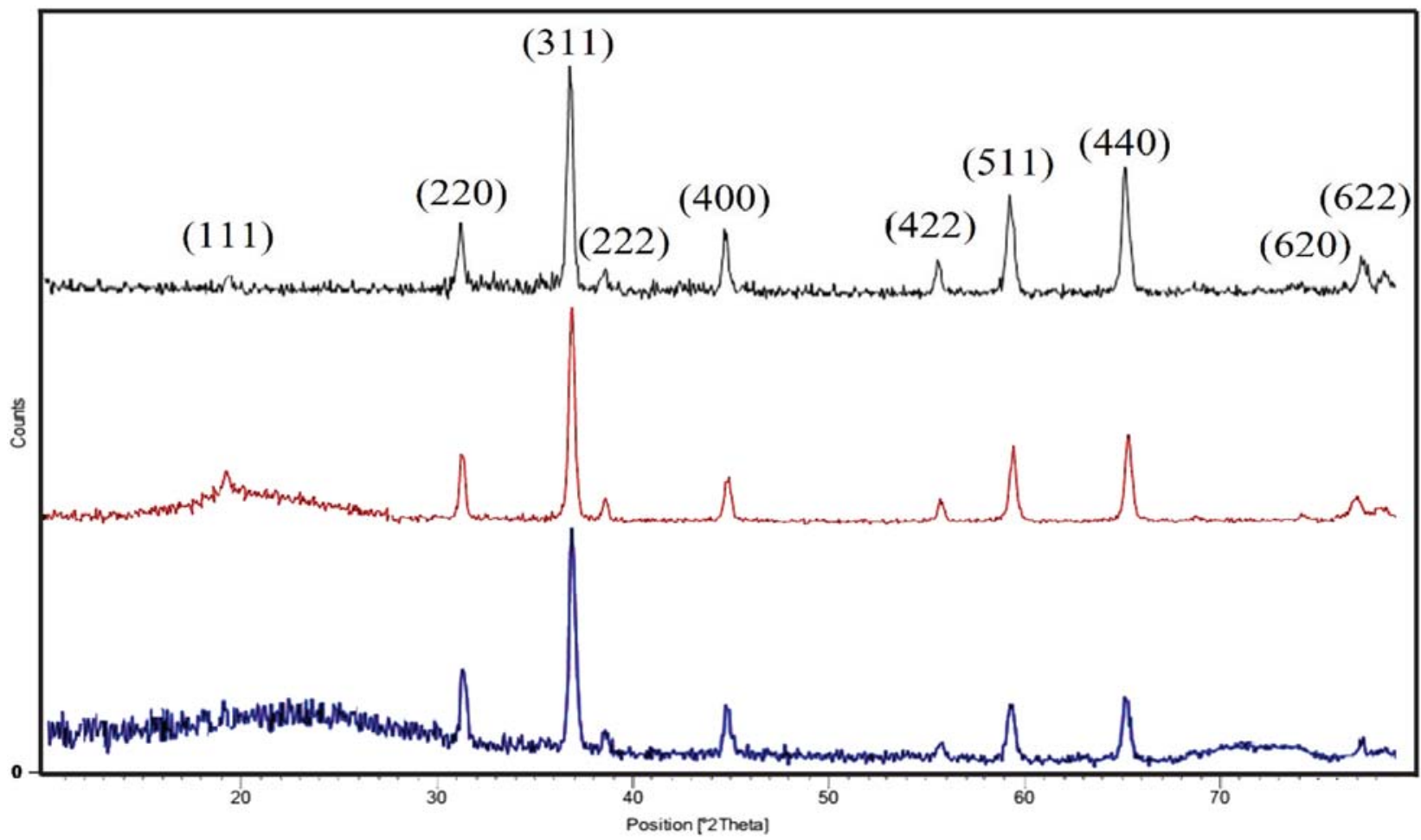

Figure 1. X-ray diffraction of $\mathrm{Co}_{3} \mathrm{O}_{4}(\mathrm{a}), \mathrm{Co}_{3} \mathrm{O}_{4} @ \mathrm{SiO}_{2}(\mathrm{~b})$ and $\mathrm{Co}_{3} \mathrm{O}_{4} @ \mathrm{SiO}_{2}-\mathrm{NH}_{2}$ (c) $\mathrm{MNPs}$.

shown in Figure 2. For all three nanoparticles, the analyses indicated two strong absorption bands at 565 and $662 \mathrm{~cm}^{-1}$ which correspond to the vibrations of $\mathrm{Co}-\mathrm{O}$ in $\mathrm{Co}_{3} \mathrm{O}_{4}$.
The peaks at 460 and $1070 \mathrm{~cm}^{-1}$ are attributed to the $\mathrm{Si}-\mathrm{O}-\mathrm{Si}$ bond stretching of $\mathrm{Co}_{3} \mathrm{O}_{4} @ \mathrm{SiO}_{2}$ and $\mathrm{Co}_{3} \mathrm{O}_{4} @$ $\mathrm{SiO}_{2} @ \mathrm{NH}_{2}$. The weak intensity band at $830 \mathrm{~cm}^{-1}$ can be

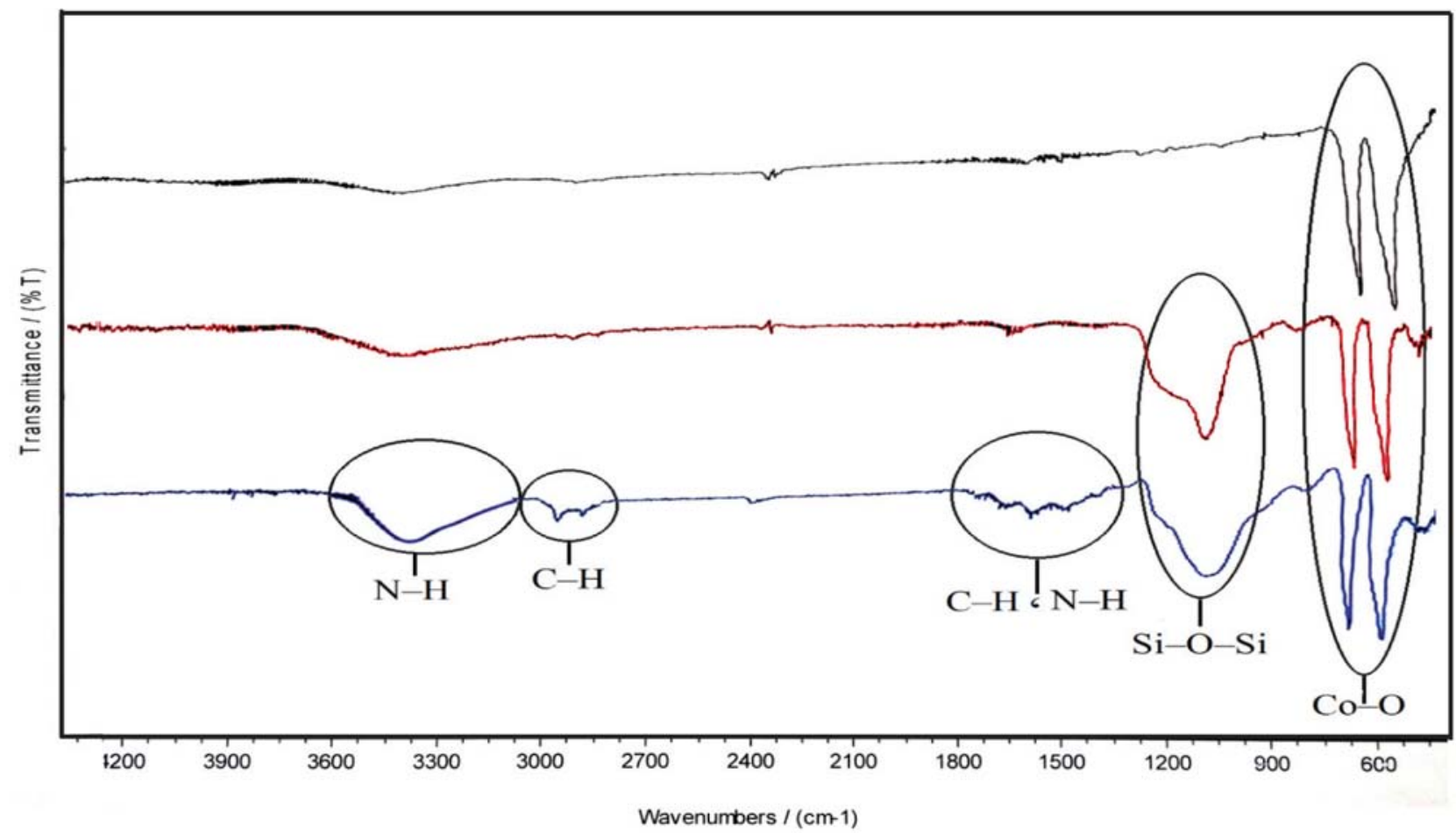

Figure 2. Comparative FT-IR spectra of $\mathrm{Co}_{3} \mathrm{O}_{4}(\mathrm{a}), \mathrm{Co}_{3} \mathrm{O}_{4} @ \mathrm{SiO}_{2}$ (b) and $\mathrm{Co}_{3} \mathrm{O}_{4} @ \mathrm{SiO}_{2}-\mathrm{NH}_{2}$ (c) MNPs. 

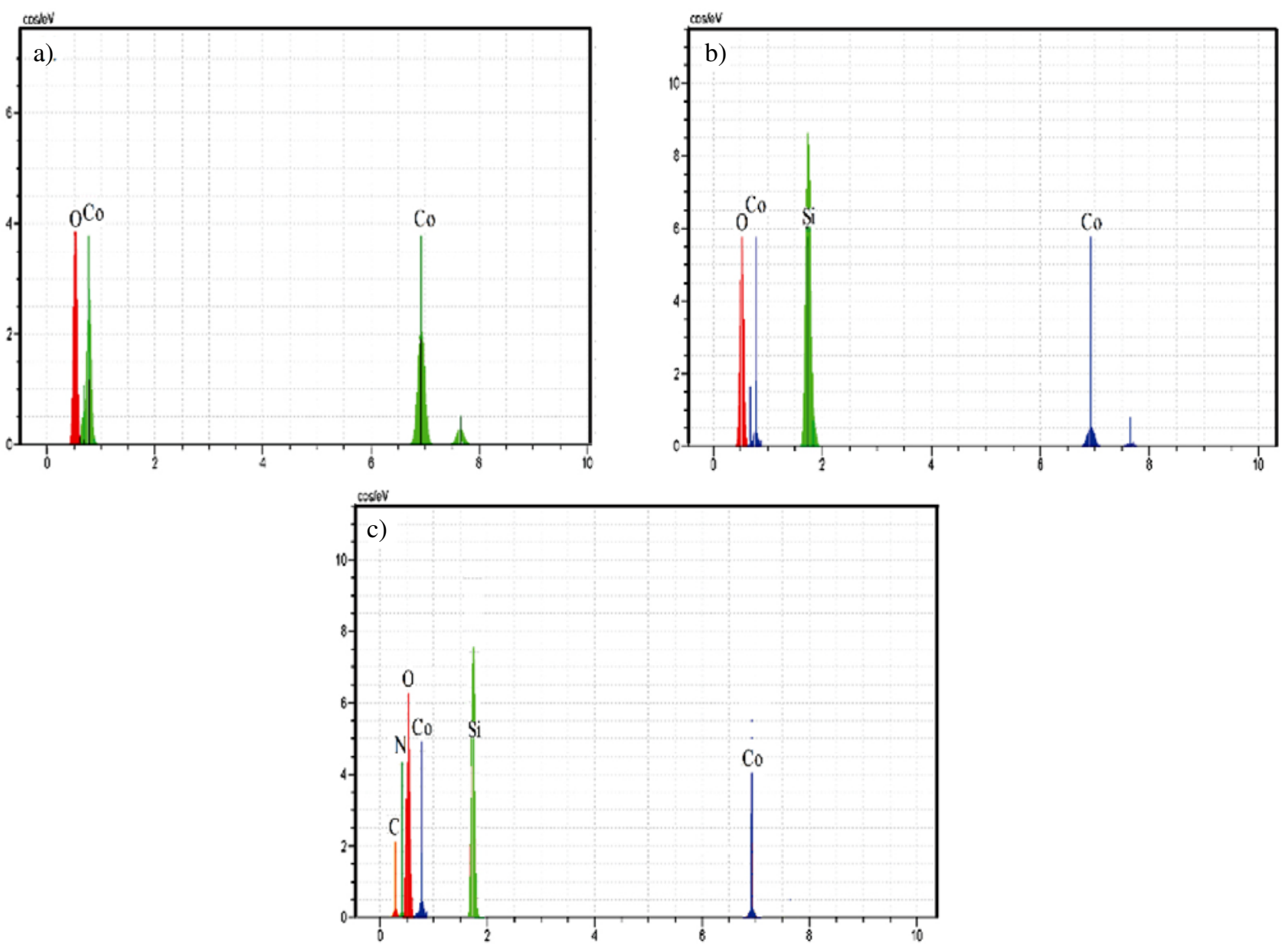

Figure 3. EDX spectra of $\mathrm{Co}_{3} \mathrm{O}_{4}(\mathrm{a}), \mathrm{Co}_{3} \mathrm{O}_{4} @ \mathrm{SiO}_{2}$ (b) and $\mathrm{Co}_{3} \mathrm{O}_{4} @ \mathrm{SiO}_{2}-\mathrm{NH}_{2}$ (c) MNPs.

ascribed to the stretching of non-bridging oxygen atom in $\mathrm{Si}-\mathrm{OH}$ bond. Therefore the silica coating on the surface of $\mathrm{Co}_{3} \mathrm{O}_{4}$ nanoparticles were confirmed by these absorption bands (Figure $2 \mathrm{~b}$ and $2 \mathrm{c}$ ). As indicated in Figure 2c, the peaks of $\mathrm{Co}_{3} \mathrm{O}_{4} @ \mathrm{SiO}_{2} @ \mathrm{NH}_{2}$ are located at $1480 \mathrm{~cm}^{-1}$ (C-H bending), $2880 \mathrm{~cm}^{-1}$ (C-H stretching), $1645 \mathrm{~cm}^{-1}$ ( $\mathrm{N}-\mathrm{H}$ bending), and $3360 \mathrm{~cm}^{-1}$ ( $\mathrm{N}-\mathrm{H}$ stretching). These peaks indicated that APTES has been bonded with the surface of $\mathrm{Co}_{3} \mathrm{O}_{4} @ \mathrm{SiO}_{2}$. The characteristic peaks of $\mathrm{C}-\mathrm{H}$ stretching and $\mathrm{N}-\mathrm{H}$ bending for the synthesized $\mathrm{Co}_{3} \mathrm{O}_{4} @ \mathrm{SiO}_{2} @ \mathrm{NH}_{2}$ are too weak to be observed clearly. Therefore, another analytical method, EDX, was employed to prove that the amine group has been bonded on the surface of $\mathrm{Co}_{3} \mathrm{O}_{4} @ \mathrm{SiO}_{2}{ }^{26-28}$

Figure 3 shows the EDX data for $\mathrm{Co}_{3} \mathrm{O}_{4}$, $\mathrm{Co}_{3} \mathrm{O}_{4} @ \mathrm{SiO}_{2}, \mathrm{Co}_{3} \mathrm{O}_{4} @ \mathrm{SiO}_{2} @ \mathrm{NH}_{2}$ MNPs. In Figure $3 \mathrm{c}$, the weight ratio for $\mathrm{C}: \mathrm{N}$ : O: $\mathrm{Si}$ : Co was calculated to be 12: 3.5: 36: 6.5: 42. These data demonstrate formation of $\mathrm{Co}_{3} \mathrm{O}_{4} @ \mathrm{SiO}_{2} @ \mathrm{NH}_{2}$ nanocomposite.

Figure 4 represents the room-temperature magnetization curves of the $\mathrm{Co}_{3} \mathrm{O}_{4}, \mathrm{Co}_{3} \mathrm{O}_{4} @ \mathrm{SiO}_{2}$ and $\mathrm{Co}_{3} \mathrm{O}_{4} @$ $\mathrm{SiO}_{2}-\mathrm{NH}_{2}$ MNPs which have been obtained using a VSM. As it can be observed, there are no hysteresis, coercivity and remanence in the three synthesized nanoparticles which indicate their typical superparamagnetic property. The plots which have been shown in Figure 4 exhibited a change in saturation magnetization (Ms) of the particles

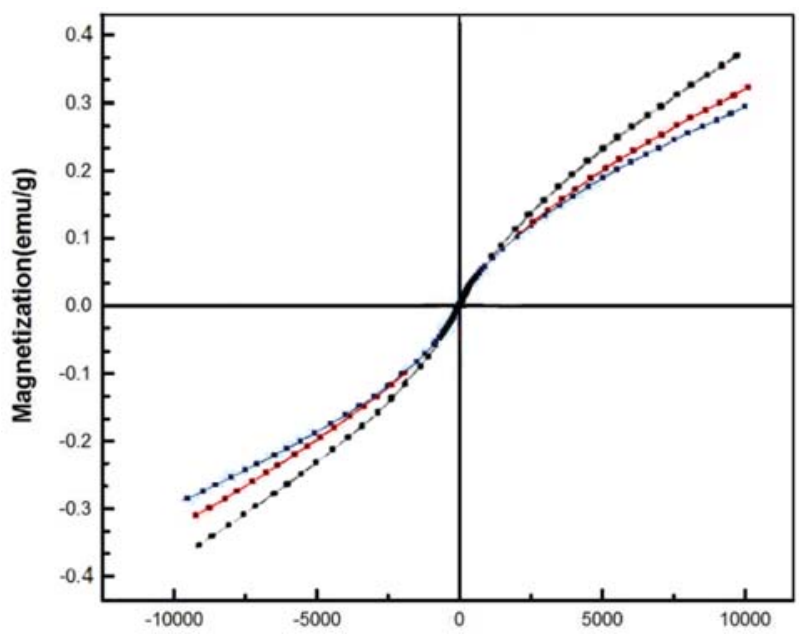

Figure 4. VSM magnetization curves of the $\mathrm{Co}_{3} \mathrm{O}_{4}$ (a), $\mathrm{Co}_{3} \mathrm{O}_{4} @$ $\mathrm{SiO}_{2}$ (b) and $\mathrm{Co}_{3} \mathrm{O}_{4} @ \mathrm{SiO}_{2}-\mathrm{NH}_{2}$ (c) MNPs. 
after incorporation of a $\mathrm{NH}_{2} / \mathrm{SiO}_{2}$ shell. The Ms values were measured to be $47.1,36.9$ and $33.8 \mathrm{emu} / \mathrm{g}$ respectively. It is clear that saturation magnetization of silica-coated $\mathrm{Co}_{3} \mathrm{O}_{4}$ nanoparticles is lower than that of pristine $\mathrm{Co}_{3} \mathrm{O}_{4}$ nanoparticles, and saturation magnetization of $\mathrm{Co}_{3} \mathrm{O}_{4} @ \mathrm{SiO}_{2}-\mathrm{NH}_{2}$ is lower than $\mathrm{Co}_{3} \mathrm{O}_{4} @ \mathrm{SiO}_{2}$. This reduction in saturation magnetization can be attributed to the surface effects such as magnetically inactive layer which contains spins that are not collinear with the magnetic field. ${ }^{29}$ Because the silica coating is a nonmagnetic mass, and this decrease was ascribed to the contribution of the nonmagnetic $\mathrm{NH}_{2} / \mathrm{SiO}_{2}$ shell to the total mass of the particles.

Figure 5 shows TEM image of amino-functionalized $\mathrm{SiO}_{2}$ coated $\mathrm{Co}_{3} \mathrm{O}_{4}$ nanoparticles. Typical size of the structure has been measured about $50 \mathrm{~nm}$, and the aggregation of the nanoparticles can be observed clearly. Therefore, the TEM observation confirmed the formation of an amino-functionalized $\mathrm{SiO}_{2}$ around the $\mathrm{Co}_{3} \mathrm{O}_{4}$ nanoparticles with typical nanostructure.

The scanning electron microscopy (FE-SEM) of the $\mathrm{Co}_{3} \mathrm{O}_{4} @ \mathrm{SiO}_{2} @ \mathrm{NH}_{2}$ MNPs shows the morphology and structure of the as-prepared samples (Figure 6). The $\mathrm{Co}_{3} \mathrm{O}_{4}$ nanoparticles are irregular sheets (non-spherical) in shape and hard aggregated powders with diameters ranging from 35 to $80 \mathrm{~nm}$ as seen in Figure 6a. The irregular Bullet-shaped $\mathrm{Co}_{3} \mathrm{O}_{4} @ \mathrm{SiO}_{2}$ nanoparticles with diameters ranging from 95 to $220 \mathrm{~nm}$ are shown in Figure 6b. This illustrated that $\mathrm{SiO}_{2}$ has been successfully coated on the $\mathrm{Co}_{3} \mathrm{O}_{4}$ nanoparticles. The micrograph of

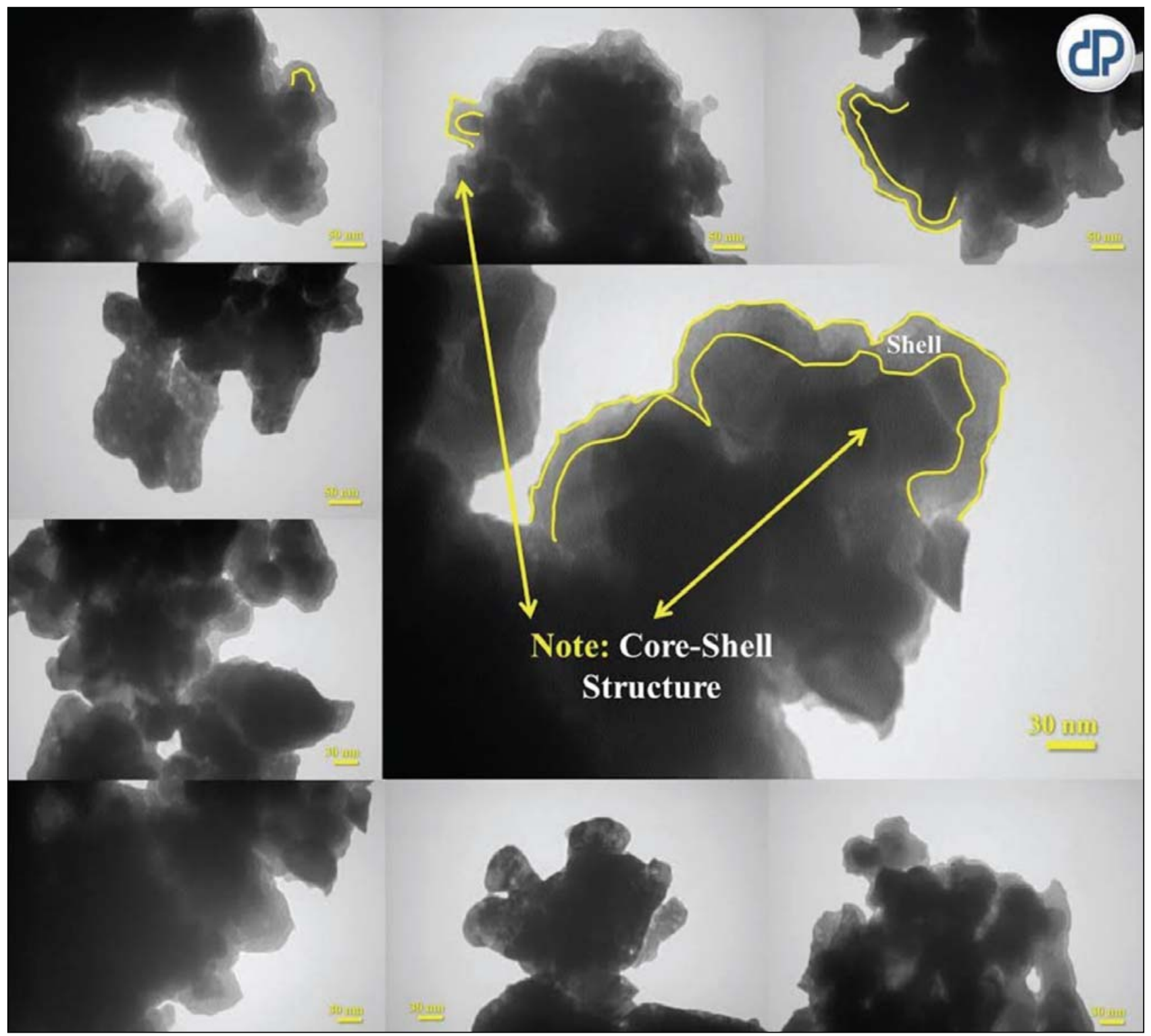

Figure 5. TEM images of $\mathrm{Co}_{3} \mathrm{O}_{4} @ \mathrm{SiO}_{2} @ \mathrm{NH}_{2} \mathrm{MNPs}$ 


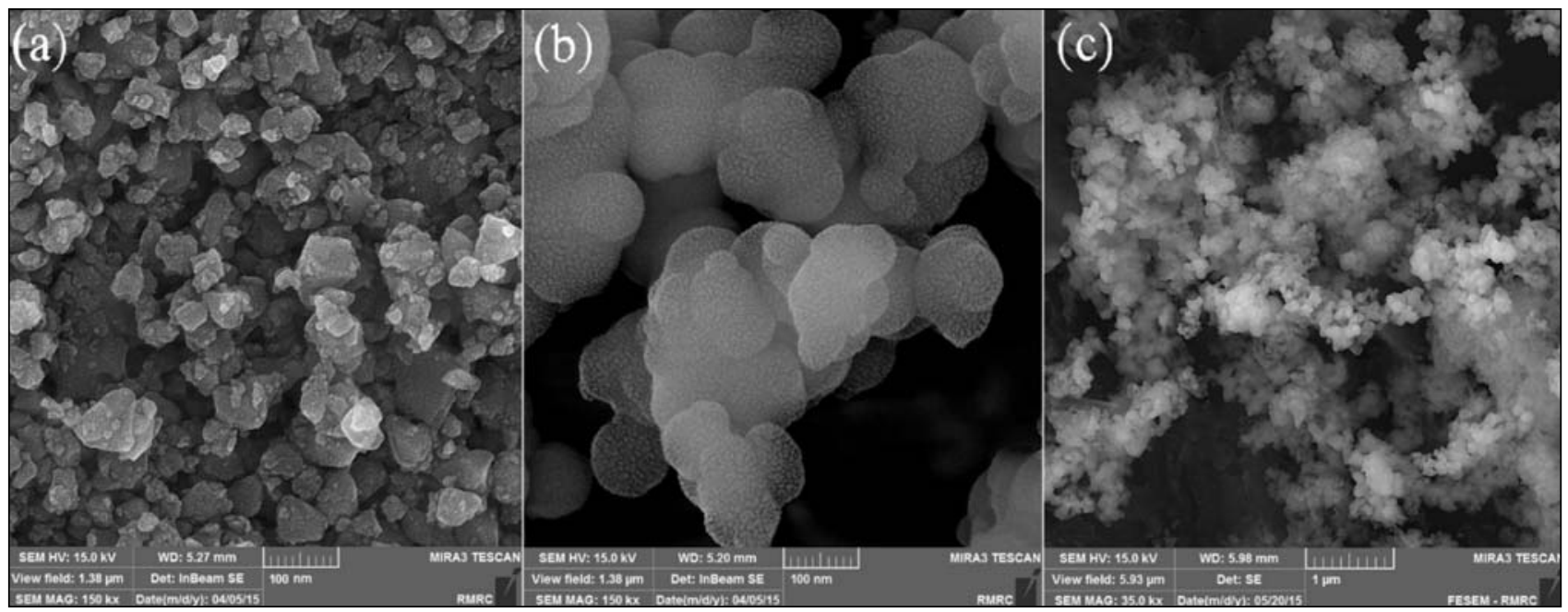

Figure 6. $\mathrm{SEM}$ images of $\mathrm{Co}_{3} \mathrm{O}_{4}(\mathrm{a}), \mathrm{Co}_{3} \mathrm{O}_{4} @ \mathrm{SiO}_{2}$ (b) and $\mathrm{Co}_{3} \mathrm{O}_{4} @ \mathrm{SiO}_{2}-\mathrm{NH}_{2}$ (c) MNPs.

$\mathrm{Co}_{3} \mathrm{O}_{4} @ \mathrm{SiO}_{2} @ \mathrm{NH}_{2} \mathrm{MNPs}$ represents a cloudy network of particles with spherical shape, as indicated in TEM image. This network is the result of self-poly condensation of aminopropylsilane groups.

\section{2. Catalyst Testing for the Synthesis of Some 7-benzylidene-2,3-diphenyl- 3,3a,4,5,6,7-hexahydro-2H-indazole Derivatives}

In order to optimize the reaction conditions and to obtain the best catalytic activity, the synthesis of 7-benzylidene-2,3-diphenyl-3,3a,4,5,6,7-hexahydro-2H-indazole derivatives was chosen as a model reaction. The reactions were conducted under solvent-free conditions at $80{ }^{\circ} \mathrm{C}$ (Scheme 2).

The synthesis of 7-benzylidene-2,3-diphenyl3,3a,4,5,6,7-hexahydro-2H-indazoles with different amounts of the $\mathrm{Co}_{3} \mathrm{O}_{4} @ \mathrm{SiO}_{2} @ \mathrm{NH}_{2} \mathrm{MNPs}$ has been considered. It was observed that while the amount of catalyst increased from 0 to $0.003 \mathrm{~g}$, the product yield raised from $0 \%$ to $98 \%$ significantly. No reaction yield without using the catalyst corroborates that the $\mathrm{Co}_{3} \mathrm{O}_{4} @ \mathrm{SiO}_{2} @ \mathrm{NH}_{2}$ MNP catalyst plays a pivotal role in the synthesis of 7-benzylidene-2,3-diphenyl-3,3a,4,5,6,7-hexahydro-2Hindazole derivatives.
In the respect of industrial aims, reusability of the catalyst was examined by repeating the model reaction under the optimizedreaction conditions (Table 1). In order to reuse the catalyst after each cycle, it was separated by a magnet, washed several times with deionized water and chloroform. Then, it was dried in oven at $60^{\circ} \mathrm{C}$ and reused in the next run. According to the results, the $\mathrm{Co}_{3} \mathrm{O}_{4} @$ $\mathrm{SiO}_{2} @ \mathrm{NH}_{2}$ MNPs can be reused six times without any significant loss of activity in this organic reaction. Moreover, nitrogen content of the catalyst was estimated by back titrationafter sixth cycle $(5.72 \mathrm{mmol} / \mathrm{g})$, which indicates low $\mathrm{NH}_{2}$ leaching during the reaction.

Table 1. Reusability of the $\mathrm{Co}_{3} \mathrm{O}_{4} @ \mathrm{SiO}_{2}-\mathrm{NH}_{2}$ nanocomposite

\begin{tabular}{cccccc}
\hline First & Second & Third & $\begin{array}{c}\text { Yield (\%) } \\
\text { Fourth }\end{array}$ & Fifth & Sixth \\
\hline 98 & 96 & 95 & 92 & 91 & 87 \\
\hline
\end{tabular}

In order to evaluate scope of this research, we tried to prepare a range of 7-benzylidene-2, 3-diphenyl3,3a, 4,5,6,7-hexahydro-2H-indazole derivatives under the same reaction conditions. The results are presented in (Table 2). ${ }^{30}$<smiles>O=C1C(=CBr)CCCC1=CBr</smiles>

$1(a-e)$<smiles>Nc1ccccc1</smiles>

2<smiles>Br/C=C1\CCCC2C1=NN(c1ccccc1)C2Br</smiles>

3(a-e)

Scheme 2. The model reaction for the synthesis of 7-benzylidene-2,3-diphenyl-3,3a,4,5,6,7-hexahydro-2H-indazole 
Table 2. $\mathrm{Co}_{3} \mathrm{O}_{4} @ \mathrm{SiO}_{2}-\mathrm{NH}_{2}$ catalyzed synthesis of some indazoles ${ }^{\mathrm{a}}$

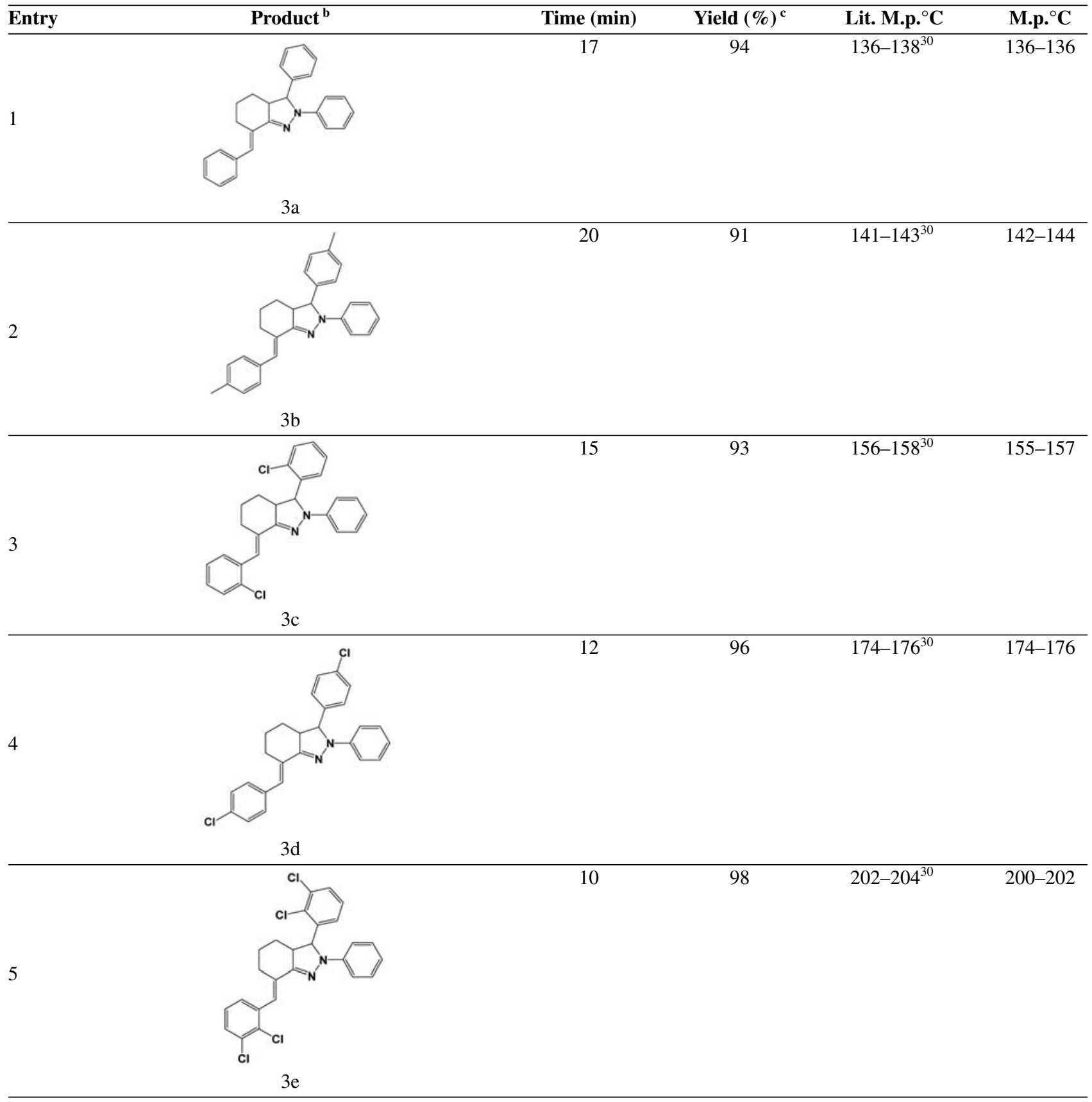

${ }^{a}$ Reaction conditions: phenyl hydrazine $(1 \mathrm{mmol}), \alpha, \alpha$-bis (substituted-arylidene) cycloalkanone $(1 \mathrm{mmol})$, catalyst $\left(0.003 \mathrm{~g}, \mathrm{Co}_{3} \mathrm{O}_{4} @ \mathrm{SiO}_{2}-\mathrm{NH}_{2}\right)$, under solvent-free conditions at $80{ }^{\circ} \mathrm{C}{ }^{\text {b }}$ Products were characterized by FT-IR, ${ }^{1} \mathrm{H} N M R$ and ${ }^{13} \mathrm{C}$ NMR analysis ${ }^{\mathrm{c}}$ Isolated yield.

\section{Conclusions}

In this research, $\mathrm{Co}_{3} \mathrm{O}_{4}$ nanoparticles were coated with amino-functionalized $\mathrm{SiO}_{2}$ as organic shell via three step method. The average crystallite size of the $\mathrm{Co}_{3} \mathrm{O}_{4}$ was calculated $23.7 \mathrm{~nm}$, by using the Scherrer equation. The synthesized nanocomposite exhibited super paramagnetic behaviour at room temperature because of the magneti- cally inactive layer of $\mathrm{SiO}_{2} @ \mathrm{NH}_{2}$. The saturation magnetization of $\mathrm{Co}_{3} \mathrm{O}_{4} @ \mathrm{SiO}_{2} @ \mathrm{NH}_{2} \mathrm{MNPs}$ is less than that of pure $\mathrm{Co}_{3} \mathrm{O}_{4}$ nanoparticles. This new magnetic nanocomposite showed the following advantages: (a) simple preparation; (b) recoverability and easy separation by an external magnet, c) highly effective for chemical transformations as a heterogeneous catalyst. These unique results open new perspectives for application of these types of 
magnetic nanocomposites in many reactions. Moreover, we have developed a facile, convenient and environmentally benign synthesis of some 7-benzylidene-2,3-diphenyl-3,3a,4,5,6,7-hexahydro- $2 \mathrm{H}$-indazole derivatives by utilizing novel nano-scale materials including $\mathrm{Co}_{3} \mathrm{O}_{4} @$ $\mathrm{SiO}_{2} @ \mathrm{NH}_{2}$ nanocomposite.

\section{Acknowledgements}

This work is funded by the Research Affairs Office of the Islamic Azad University, Qom Branch, Qom, I. R. Iran grant number 2014-13929].

\section{References}

1. K. K. Senapati, S. Roy, C. Borgohain, P. Phukan, J. Mol. Catal. A Chem., 2012, 352, 128-134. https://doi.org/10.1016/j.molcata.2011.10.022

2. D. Lee, J. Lee, H. Lee, S. Jin, T. Hyeon, B. M. Kim, $A d v$. Synth. Catal., 2006, 348, 41-46. https://doi.org/10.1002/adsc.200505354

3. R. Abu-Rezig, H. Alper, D. Wang, M. L. Post, J. Am. Chem. Soc., 2006, 128, 5279-5282. https://doi.org/10.1021/ja060140u

4. S. Zafeiratos, T. Dintzer, D. Teschner, R. Blume, M. Hävecker, A. Knop-Gericke, and R Schlogl, J. Catal., 2010, 269, 309-317. https://doi.org/10.1016/j.jcat.2009.11.013

5. A. Yu. Khodakov, J. Lynch, D. Bazin, B. Rebours, N. Zanier, B. Moisson, P. Chaumette, J. Catal., 1997, 168, 16-25. https://doi.org/10.1006/jcat.1997.1573

6. D. Yang, J. Hu, S. Fu, J. Phys. Chem. C., 2009, 113, 76467651. https://doi.org/10.1021/jp900868d

7. Z. Bo, X. JianMin, L. Yu Qi, L. HuiZhou, Sci China Ser BChem., 2008, 51, 145-151.

8. C. W. Lu, Y. Hung, J. K. Hsiao, M. Yao, T. H. Chung, Y. S. Lin, S. H. Wu, S. C. Hsu, H. M. Liu, C. Y. Mou, C. S. Yang, D. M. Huang, Y. C. Chen, Nano Lett., 2007, 7, 149-154. https://doi.org/10.1021/n10624263

9. P. Ashtari, X. X. He, K. Wang, P. Gong, Talanta., 2005, 67, 548-554. https://doi.org/10.1016/j.talanta.2005.06.043

10. X. Zhao, Y. Shi, T. Wang, Y. Cai, G. Jiang, J. Chromatogr. A., 2008, 1188, 140-147. https://doi.org/10.1016/j.chroma.2008.02.069

11. C. A. Mirkin, MRS Bull., 2000, 25, 43-54. https://doi.org/10.1557/mrs2000.123

12. M. Bagheri, M. Masteri-Farahani, M. Ghorbani, J. Magn. Magn. Mater., 2013, 327, 58-63. https://doi.org/10.1016/j.jmmm.2012.09.038

13. T. Z. Yang, C. M. Shen, H. J. Gao, J. Phys. Chem. B., 2005, 109, 23233-23236. https://doi.org/10.1021/jp054291f

14. M. A. Ghasemzadeh, M. H. Abdollahi-Basir, Acta. Chim. Slov. 2016, 63, 627-637. https://doi.org/10.17344/acsi.2016.2386

15. M. A. Ghasemzadeh, Acta. Chim. Slov., 2015, 62, 977-985. https://doi.org/10.17344/acsi.2015.1501

16. J. Safaei-Ghomi, M. A. Ghasemzadeh, J. Serb. Chem. Soc., 2011, 75, 679-684.

17. F. Zamani, S. Kiapour, Catal. Commun., 2014, 45, 1-6. https://doi.org/10.1016/j.catcom.2013.10.027

18. F. Zamani, S. M. Hosseini, Catal. Commun., 2014, 43, 164168. https://doi.org/10.1016/j.catcom.2013.09.029

19. G. H. Mahdavinia, S. Rostamizadeh, A. M. Amani, M. Mirzazadeh, Green Chem. Lett. Rev., 2012, 5, 255-281. https://doi.org/10.1080/17518253.2011.617317

20. G. H. Mahdavinia, M. Mirzazadeh, E. J. Chem., 2012, 9, 49-54. https://doi.org/10.1155/2012/390528

21. C. C. Lin, Y. Guo, J. Vela, ACS Catal., 2015, 5, 1037-1044. https://doi.org/10.1021/cs501650j

22. J. Alauzun, A. Mehdi, C. Reyé, R. J. P. Corriu, J. Am. Chem. Soc., 2006, 128, 8718-8719. https://doi.org/10.1021/ja0622960

23. Y. Shao, J. Guan, S. Wu, H.Liu, B. Liu, Q. Kan, Microporous Mesoporous Mater., 2010, 128, 120-125. https://doi.org/10.1016/j.micromeso.2009.08.013

24. F. Zamani, E. Izadi, Chin. J. Catal., 2014, 35, 21-27 https://doi.org/10.1016/S1872-2067(12)60685-8

25. C. Suryanarayana, M. G. Norton, X-Ray Diffraction: A Practical Approach, Plenum Press, 1998. https://doi.org/10.1007/978-1-4899-0148-4

26. J. Wang, S. Zheng, Y. Shao, J. Liu, Z. Xu, D. Zhu, J. Colloid Interface Sci., 2010, 349, 293-299. https://doi.org/10.1016/j.jcis.2010.05.010

27. A. A. M. Gomaa, F. A. Osama, M. A. Salah, Y. M. Mashitah, C. F. Feng, J. Solid State Electro. chem., 2014, 18, 25052512. https://doi.org/10.1007/s10008-014-2510-3

28. S. Esposito, M. Turco, G. Ramis, G. Bagnasco, P. Pernice, C. Pagliuca, M. Bevilacqua, J Solid State Chem., 2007, 180, 3341-3350. https://doi.org/10.1016/j.jssc.2007.09.032

29. M. Yamaura, R. L. Camilo, L. C. Sampaiob, M. A. Macedoc, M. Nakamurad, H. E. Tomad, J. Magn. Magn. Mater., 2004, 279, 210-217. https://doi.org/10.1016/j.jmmm.2004.01.094

30. G. H. Mahdavinia, M, Mirzazadeh, Z. Karimi-Jaber, Green Chem Lett. Rev., 2015, 8, 13-15. https://doi.org/10.1080/17518253.2014.976280 


\section{Povzetek}

V tej raziskavi poročamo o učinkoviti sintezni poti v treh stopnjah s katero smo pripravili nov nanokompozit kobaltovega oksida $\left(\mathrm{Co}_{3} \mathrm{O}_{4}\right)$ prevlečen s $\mathrm{SiO}_{2} @$ (3-aminopropil)-trietoksisilanom. Strukturne in magnetne lastnosti kompozita $\mathrm{Co}_{3} \mathrm{O}_{4} @ \mathrm{SiO}_{2} @ \mathrm{NH}_{2}$ smo določili s pomočjo različnih metod: infrardečo spektroskopijo (FT-IR), rentgensko praškovno difrakcijo, vrstično elektronsko mikroskopijo (SEM), presevno elektronsko mikroskopijo (TEM), energijsko disperzijsko spektroskopijo (EDX) in magnetometrijo z vibrirajočim vzorcem (VSM). V nanokompozitu $\mathrm{Co}_{3} \mathrm{O}_{4}, \mathrm{ki} \mathrm{je} \mathrm{pre-}$ vlečen $\mathrm{z}$ amino funkcionaliziranim $\mathrm{SiO}_{2}$ je opaziti superparamagnetne lastnosti in močno magnetizacijo pri sobni temperaturi. Povprečne velikosti kristalitov $\mathrm{Co}_{3} \mathrm{O}_{4}$ so $23,7 \mathrm{~nm}$. Dobljeni magnetni nanokompozit je pokazal odlično katalitsko aktivnost kot novi heterogeni magnetni katalizator za sintezo nekaterih derivatov indazola pri blagih reakcijskih pogojih in visoko stopnjo ponovne uporabe. 